\title{
Diet Composition of Cattle Grazing Sandhills Range During Spring
}

\author{
Jerry D. Volesky, ${ }^{1}$ Walter H. Schacht, ${ }^{2}$ Patrick E. Reece, ${ }^{3}$ and \\ Timothy J. Vaughn ${ }^{4}$ \\ Authors are ${ }^{1}$ Associate Professor, University of Nebraska-Lincoln, West Central Research and Extension Center, North Platte, \\ NE 69101; ${ }^{2}$ Professor, Agronomy and Horticulture Department, University of Nebraska-Lincoln, Lincoln, NE 68583; \\ ${ }^{3}$ Professor, University of Nebraska-Lincoln, Panhandle Research and Extension Center, Scottsbluff, NE 69361; and \\ ${ }^{4}$ Former Graduate Research Assistant, 14460 N. Sand Road, Hershey, NE 69143.
}

\begin{abstract}
The grazing season on upland Sandhills range traditionally begins in mid-May when the dominant warm-season grasses have initiated growth. Initiating grazing earlier would improve efficiency of use of cool-season plants and reduce the time period during which hay is fed. A 2-year study was conducted to determine nutrient and botanical composition of cattle diets when grazing upland Sandhills range during spring. Diets were collected from esophageally-fistulated cows on 10 April, 1 May, and 22 May each year. Concurrently, current-year, and residual herbage was clipped to determine pasture composition and calculate preference indices for the primary plant species and groups. Averaged across dates, needleandthread (Stipa comata Trin. \& Rupr.), bluegrasses (Poa spp.), and sedges (Carex spp.) accounted for $19 \%$ of the total herbage and $68 \%$ of the current-year herbage yield. These species constituted an average of $74 \%$ of cow diets. Diet composition of sedges was less on 10 April than on 22 May $(P<0.05)$, whereas similar amounts of needleandthread and bluegrasses were present on all dates. Preference indices indicated strong selection for species with abundant current-year growth and avoidance of residual herbage. Crude protein content of diets was less on 10 April $(10.7 \%)$ than on 1 May or 22 May $(13.9 \%, P<0.05)$, likely because of a greater amount of residual herbage present in 10 April diets. Overall quality of diets would meet requirements of average spring-calving cows; however, grazing management strategies would need to account for the limited availability of current-year growth during spring, particularly April, to ensure that cattle are meeting their nutrient needs.
\end{abstract}

\section{Resumen}

La época de apacentamiento en las mesetas de los pastizales "Sandhills" tradicionalmente inicia a mediados de Mayo cuando los zacates dominantes de estación caliente han iniciado el rebrote. Comenzar el apacentamiento más temprano mejoraría la eficiencia del uso de las plantas de estación fría y reduce el tiempo de suministro de heno. Se condujo un estudio de dos años para determinar la composición botánica y nutritiva de las dietas del ganado cuando apacientan las mesetas de los pastizales "Sandhills" en primavera. Se usaron vacas con fístula esofágica para colectar las dietas el 10 de Abril, 1 y 22 de Mayo de cada año. Al mismo tiempo, se cosechó el forraje del año en curso y el forraje residual para determinar la composición botánica de la pradera y calcular los índices de preferencia de las principales especies y grupos. Promediado a través de fechas, las especies "Needleandthread" (Stipa comata Trin. \& Rupr.), "Bluegrasses" (Poa spp.), y "Sedges" (Carex spp.) aportaron el 91\% del forraje total y el $68 \%$ del rendimiento del año en curso, estas especies constituyeron en promedio $74 \%$ de las dietas de las vacas. El porcentaje "Sedges" en la dieta fue menor el 10 de Abril 10 que el 22 de Mayo $(P<0.05)$, mientras que para el "Needleandthread" y "Bluegrasses" las cantidades presentes en todas las fechas fueron similares. Los índices de preferencia indicaron una fuerte selección de especies con abundante crecimiento del año y evitaron el forraje residual. El contenido de proteína cruda de las dietas fue menor el 10 de Abril $(10.7 \%)$ que el 1 y 22 de Mayo $(13.8 \%, P<0.05)$, probablemente debido a la mayor cantidad de forraje residual presente en las dietas del 10 de Abril. La calidad general de las dietas pudiera satisfacer los requerimientos de las vacas promedio paridas en primavera, sin embargo, se necesitarían estrategias de manejo del apacentamiento que tomen en cuenta la disponibilidad limitada de forraje del año en curso durante primavera, particularmente en Abril, para asegurar que el ganado esta satisfaciendo sus requerimientos nutricionales.

Key Words: diet botanical composition, diet quality, diet selection, preference index

\section{INTRODUCTION}

This is a contribution of the University of Nebraska Agricultural Research Division, supported in part by funds provided through the Hatch Act. Additional support was provided by University of Nebraska Foundation Anna H. Elliott Fund.

Research was a portion of degree work by T.J.V., Agronomy and Horticulture Department, University of Nebraska-Lincoln.

Correspondence: Jerry D. Volesky, West Central Research and Extension Center, 461 West University Dr, North Platte, NE 69101. Email: jvolesky1@unl.edu

Manuscript received 21 December 2005; manuscript accepted 11 September 2006.
Diet selection of cattle grazing native grasslands is an interactive process, based on preferences of the animal, constrained by animal characteristics, and is in response to available herbage and its nutritive quality and physical characteristics (Ellis et al. 1976; Stuth 1991). The selection process is dynamic because animal and plant characteristics change temporally (Wallace et al. 1972). The nutritive value of plants changes with phenol- 
ogy and changes in leaf:stem ratio. Knowledge of the nutritive value and availability of forage selected by cattle is critical for supplementation programs and for changing calving or weaning dates when synchronizing cow nutrient requirements with available forage resources (Vavra and Raleigh 1976; Vallentine 1990). Additionally, knowledge of diet botanical composition and plant preferences can help managers better allocate forage to different herbivores (including wildlife), evaluate competition, and still maintain proper use of forage resources (Uresk 1986). Numerous studies have characterized botanical and/or nutritive composition of cattle diets on varying rangeland types and conditions (Rosiere et al. 1975a, 1975b; Powell et al. 1982), under different grazing systems (Pfister et al. 1984; Kirby and Parman 1986), or seasons (Wallace et al. 1972; Holecheck et al. 1982). On Nebraska Sandhills rangeland, studies have focused on the nutritive content of diets collected from esophageallyfistulated cattle during different seasons (Villalobos 1993; Hollingsworth-Jenkins et al. 1996; Lardy et al. 1999). However, information on botanical composition of diets on this type of rangeland is lacking.

The Sandhills region covers nearly 5 million ha in central and western Nebraska and stretches into South Dakota (Bleed and Flowerday 1998). Vegetation of upland range is dominated by warm-season grasses with lesser amounts of cool-season grasses, sedges (Carex spp.), forbs, and shrubs (Barnes and Harrison 1982). Beef cattle production is the principal use of this vast grassland. Traditionally, the "summer" grazing season on upland range in the Sandhills begins in mid-May and lasts through October (Coady and Clark 1993). Earlier turnout dates are of interest to many livestock producers because of the lower cost of grazing compared to feeding hay (Adams et al. 1994). The objectives of this study were to (1) quantify nutrient and botanical composition of diets of cattle when grazing upland Sandhills range during spring, and (2) determine relative preference indices for the primary plant species and groups. We hypothesized that cattle would prefer current-year growth of cool-season species and that diet quality would meet animal requirements.

\section{MATERIAL AND METHODS}

\section{Study Area}

The study was conducted in 2000 and 2001 at the University of Nebraska's Gudmundsen Sandhills Laboratory located $11 \mathrm{~km}$ northeast of Whitman, Nebraska (lat $42^{\circ} 04^{\prime} \mathrm{N}$, long $101^{\circ} 26^{\prime} \mathrm{W}$, elevation $=1075 \mathrm{~m}$ ). The average maximum daily temperatures range from $2^{\circ} \mathrm{C}$ in January to $32^{\circ} \mathrm{C}$ in July. Mean annual precipitation at the site is $453 \mathrm{~mm}$, about $75 \%$ of which occurs during the growing season from April through September.

The study was conducted on sands range sites (deep sands ecological site) with soils classified as Valentine fine sands (mixed, mesic Typic Ustipsamments). Study pastures were in an area that had been used exclusively for dormant-season (October to March) grazing the previous 8 years and were in good to excellent range condition. August current-year standing crop at this site averaged $1260 \mathrm{~kg} \cdot \mathrm{ha}^{-1}$ and was comprised of $52 \%$ warm-season grasses, $36 \%$ cool-season species (grasses and sedges), and 12\% forbs (Volesky et al. 2005). Warm-season grasses, including prairie sandreed, (Calamovilfa longifolia [Hook.] Scribn.), sand bluestem (Andropogon hallii Hack.), switchgrass (Panicum virgatum L.), and little bluestem (Schizachyrium scoparium [Michx.] Nash) were dominant species. Major cool-season grasses were needleandthread (Stipa comata Trin. \& Rupr.), prairie junegrass (Koeleria macrantha [Ledeb.] Schult.), and Kentucky bluegrass (Poa pratensis L.). Several sedge species (Carex spp.) were present. Plant nomenclature follows Stubbendieck et al. (1997).

Nine square pastures (0.62 ha each) were established to accommodate 3 blocks of 3 diet collection dates. Blocking was based on degree of slope. Collection dates were 10 April, 1 May, and 22 May of each year. Collection dates were assigned randomly to pastures within each block. These pastures also were used in a concurrent study that examined spring grazing date and stocking rate effects on herbage yield (Volesky et al. 2005).

\section{Diet Quality and Composition}

Diet samples were collected on each spring grazing date each year using 3 mature (6-12 years of age), esophageally-fistulated cows per pasture. Over the 2 years of the study, a total 8 different cows were used to collect samples. Depending on the number of cows available on a sampling date, 1 to 3 cows collected samples in 2 pastures. The cows grazed in a nearby, botanically similar pasture before and between collection dates. The afternoon before a collection date, the esophageallyfistulated cows were placed in a pen and held off feed overnight. The following morning (0800 hours), the cows were fitted with screen-bottomed bags and allowed to graze freely for 30 to 45 minutes or until about $1 \mathrm{~kg}$ of sample was collected. After collection, extrusa samples were thoroughly hand-mixed and divided into 2 portions. One portion was dedicated to quality analysis and the other to determination of botanical composition. Extrusa samples were stored frozen and then freeze-dried before analyses. Samples used for determining diet quality were ground to pass through a $1-\mathrm{mm}$ screen in a Wiley mill. Nitrogen content was determined using a LECO CHN1000 Elemental Analyzer (LECO Corporation, 3000 Lakeview Ave., St. Joseph, Mich. 49085-2396) and crude protein (CP) expressed as $\mathrm{N} \times 6.25$. Neutral detergent fiber $(\mathrm{NDF})$ was determined according to Van Soest et al. (1991), and acid detergent fiber (ADF) by the method of Van Soest (1963).

Botanical composition of cattle diets was determined using the microscope point method (Harker et al. 1964). A total of 100 points per sample were examined at $\times 15$ magnification. Plant fragments were first characterized as current-year growth (green) or residual (previous year's growth). Secondly, fragments were quantified as either leaf or stem. Seedheads, which occurred in less than $0.1 \%$ of all sampling points, were included in the stem category. Live plant fragments were identified into the following categories: sedges (Carex spp.), needleandthread, bluegrasses (Poa spp.), prairie junegrass, western wheatgrass (Pascopyrum smithii [Rydb.] A. Love), Scribner's panicum (Panicum oligosanthes [Schult.] subsp. scribnerianum [Nash] Fern.), other cool-season grasses, prairie sandreed, other warmseason grasses, forbs, and unknown. Because of weathering and partial deterioration, no attempt was made to identify residual herbage into species or group. The recorded number of occurrences for each of these components per 100 points per sample was considered the percentage diet composition. Refer- 
Table 1. Yield ( \pm standard error [SE]) and percentage composition of current-year and residual herbage at 3 spring grazing dates on upland Sandhills range during 2000 and 2001. Within species or group, yield means with unlike letters significantly differ $(P<0.05)$.

\begin{tabular}{|c|c|c|c|c|c|c|c|}
\hline \multirow[b]{2}{*}{ Species or group } & \multicolumn{4}{|c|}{ Yield } & \multicolumn{3}{|c|}{ Percentage composition } \\
\hline & $10 \mathrm{Apr}$ & 1 May & 22 May & $\pm \mathrm{SE}$ & $10 \mathrm{Apr}$ & 1 May & 22 May \\
\hline & \multicolumn{4}{|c|}{ - } & \multicolumn{3}{|c|}{ 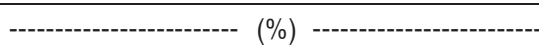 } \\
\hline Sedge spp. & $41 \mathrm{a}$ & $75 b$ & $96 \mathrm{~b}$ & 8 & 5 & 9 & 10 \\
\hline Needleandthread & $25 \mathrm{a}$ & $57 b$ & $96 c$ & 10 & 3 & 7 & 10 \\
\hline Bluegrass spp. & 29 & 33 & 44 & 7 & 4 & 4 & 4 \\
\hline Prairie junegrass & $2 a$ & $14 b$ & $20 \mathrm{~b}$ & 3 & $<1$ & 2 & 2 \\
\hline Other cool-season grasses & $13 a$ & $22 a b$ & $42 c$ & 6 & 2 & 3 & 4 \\
\hline Prairie sandreed & $0 \mathrm{a}$ & $6 b$ & $64 c$ & 4 & 0 & 1 & 7 \\
\hline Other warm-season grasses & Oa & $9 b$ & $70 c$ & 3 & 0 & 1 & 7 \\
\hline Forbs & $3 a$ & $20 b$ & $40 \mathrm{c}$ & 5 & $<1$ & 3 & 4 \\
\hline Residual $^{1}$ & $637 a$ & $554 a b$ & $510 b$ & 32 & 85 & 70 & 52 \\
\hline Total all herbage & $750 \mathrm{a}$ & $790 a$ & $982 b$ & 65 & 100 & 100 & 100 \\
\hline Total cool-season grasses ${ }^{2}$ & $113 a$ & $221 b$ & $338 c$ & 18 & 15 & 28 & 34 \\
\hline Total warm-season grasses & 0a & $15 b$ & $134 c$ & 3 & 0 & 2 & 14 \\
\hline Residual $^{2}$ & $637 a$ & $554 a b$ & $510 b$ & 32 & 85 & 70 & 52 \\
\hline Total all herbage & $750 \mathrm{a}$ & $790 a$ & $982 b$ & 65 & 100 & 100 & 100 \\
\hline
\end{tabular}

${ }^{1}$ Residual consisted of standing, previous-year herbage.

${ }^{2}$ Total cool-season includes cool-season grasses, sedges, and forbs.

ence samples of the primary plant species growing in the study pastures were prepared by hand-clipping about $1 \mathrm{~kg}$ of currentyear herbage of the individual species. These samples were individually fed to esophageally-fistulated cows and the extrusa directly collected. Reference samples were also frozen and later freeze-dried prior to examination.

\section{Herbage Yield and Range Composition}

Herbage yield was determined immediately prior to diet collections at each of the 3 spring grazing dates. A total of 30 quadrats $(25 \times 100 \mathrm{~cm})$ were randomly located in each pasture and hand-clipped to ground level. Clipped herbage was sorted into residual and current-year growth of the same species or groups as described for botanical composition of diets. Clipped samples were bagged and oven-dried at $60^{\circ} \mathrm{C}$ to a constant weight. Kentucky bluegrass was the most common bluegrass with lesser amounts of mutton bluegrass (Poa fendleriana [Steud.] Vasey), and other bluegrass species. Sun sedge (Carex heliophila Mack.) was the most common sedge species on the study site. Individually, western wheatgrass and Scribner's panicum did not account for more than $2 \%$ of the total herbage on any date and were included in the other cool-season grasses group for analysis. Six-weeks fescue (Vulpia octoflora [Walt.] Rydb.) also was present in the other cool-season grasses group. The weight of each species or group was divided by the total herbage weight (including residual) to determine percentage range composition.

Relative preference indices (RPI) were calculated for the diet components following a method described by Krueger (1972). The formula was:

$$
R P I=\frac{D}{R}
$$

where: $\mathrm{D}=$ percentage diet composition and $\mathrm{R}=$ percentage range composition.

\section{Statistical Analysis}

The experimental design was a randomized complete block with year and date as main effects. Years were considered fixed effects and blocks as random effects. All data were analyzed using the Proc Mixed procedure (Littell et al. 1996). Dependent variables included botanical composition of diets and rangeland, relative preference index values for species or plant groups, and diet quality characteristics. Mean separation was performed using the protected least squares means (LSMEANS) procedure. Potential effects of esophageally-fistulated cows on diet botanical composition, quality, and relative preference index values were evaluated in a separate analysis model. No significant cow effects were observed for any of the diet quality component. A significant difference among cows was observed only for the percentage diet composition of the other coolseason grasses group and its associated relative preference index. Effects were considered significant at $P \leq 0.05$ for all analyses unless otherwise stated.

\section{RESULTS AND DISCUSSION}

\section{Herbage Yield and Range Composition}

Total precipitation from 1 January through 22 May was 141\% and $121 \%$ of the long-term mean in 2000 and 2001, respectively. Residual herbage (previous year's growth) in the study pastures averaged $567 \mathrm{~kg} \cdot \mathrm{ha}^{-1}$ and accounted for $85 \%$, $70 \%$, and $52 \%$ of the total herbage on 10 April, 1 May, and 22 May, respectively (Table 1 ). Current-year herbage averaged $113 \mathrm{~kg} \cdot \mathrm{ha}^{-1}$ on 10 April and increased to 236 and $472 \mathrm{~kg} \cdot \mathrm{ha}^{-1}$ on 1 May and 22 May, respectively $(P<0.05)$. Averaged across dates, sedges, needleandthread, and bluegrasses had the greatest herbage yields and collectively accounted for $19 \%$ of the total herbage and $68 \%$ of the current-year herbage. The other coolseason grass group, forbs, and prairie junegrass accounted for 


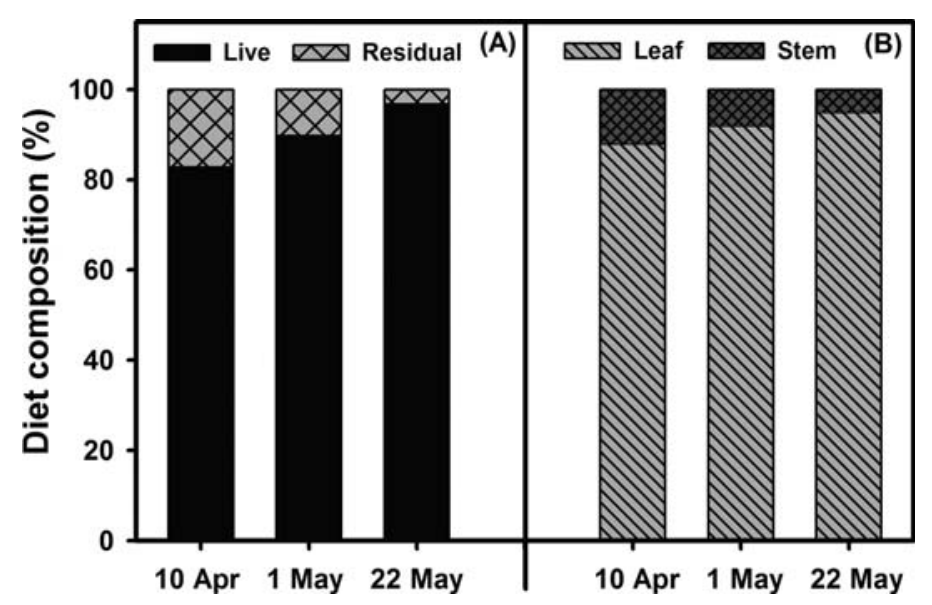

Figure 1. Percentage composition of $(\mathbf{A})$ live and residual and (B) current-year leaf and stem components in diets from esophageallyfistulated cows grazing Sandhills range during spring, 2000 and 2001. Residual consisted of dead, previous-year herbage. Within components, date means were significantly different from each other $(P<0.05)$.

$3 \%, 2 \%$, and $1 \%$ of the total herbage, respectively, and $10 \%$, $7 \%$ and $4 \%$ of the current-year herbage, respectively. The other cool-season grass group included primarily western wheatgrass, Scribner's panicum, and six-weeks fescue. Warm-season grasses did not constitute a sizeable proportion of the current-year herbage until 22 May (14\%). With the exception of bluegrasses, all species or groups had significant increases in yield after 10 April $(P<0.05)$. Additional discussion of spring herbage yield in these pastures was reported by Volesky et al. (2005).

\section{Diet Botanical Composition}

Year had no effect on percentage composition of live and residual herbage or leaf and stem components of diet samples $(P>0.05)$. Date effects were significant with percentage of live herbage increasing from $83 \%$ on 10 April to $97 \%$ on 22 May (Fig. 1A, $P<0.05$ ). The percentage of current-year leaf in diets increased from $88 \%$ on 10 April to $95 \%$ on 22 May (Fig. 1B). Correspondingly, percentages of stem components and residual herbage declined on each successive sampling date $(P<0.05)$. The relatively high percentage of leaf in diets $(\geq 88 \%)$ was expected because most species were in a vegetative stage of growth through the spring period. However, the greatest percentage of leaf was observed on 22 May, likely because of a greater number of longer leaves present at that time.
Needleandthread, bluegrasses, and sedges were the primary species or plant groups observed in diets across all sampling dates (Table 2). Together, these species accounted for about $74 \%$ of the diets. A significant year effect was present only for the other cool-season grass and other warm-season grass groups $(P<0.05)$. Percentage composition of needleandthread and bluegrasses was similar among dates $(P>0.05)$; however, percentage of sedges in diets was less on 22 May compared to 10 April $(P<0.05)$. Percentage composition of prairie junegrass and the other cool-season grasses group was significantly greater on 1 and 22 May compared to 10 April $(P<0.05)$. This was likely a function of the limited yield for those species on 10 April (Table 1). Prairie sandreed and species in the other warm-season grasses group were observed in diets on 1 May $(2.7 \%)$, but were more abundant on 22 May $(16.4 \%)$.

\section{Relative Preference Index}

Relative preference index (RPI) values for plant species and groups were consistent over years $(P>0.05)$. The RPI for sedges and needleandthread was greater on 10 April compared to 1 or 22 May $(P<0.05$, Table 3$)$. Relative preference index values for residual herbage indicated cattle consistently avoided this component of the forage resource. The level of avoidance increased as the quantity of current-year herbage increased from April through May $(P<0.05)$.

Based on preference index definitions from Rosiere et al. (1975a), there was consistently some, or definite preference $(\mathrm{RPI}=1.2-8.9)$ for the cool-season graminoids (sedges, needleandthread, and bluegrasses) that had the greatest spring yield (Table 3). Prairie junegrass and other cool-season grasses were less abundant (Table 2), but RPI also indicated some, or definite preference (RPI $=1.5-5.6)$. There were differences among cool-season graminoids with respect to growth form and distribution in the study pastures. Bluegrasses, particularly Kentucky bluegrass, tended to grow in patches on interdunal sites where soil moisture conditions were more favorable. Sedges were mostly present as single tillers or small tussocks of 2 to 5 tillers and were widely distributed across all pasture sites. Density of needleandthread and prairie junegrass tussocks was less than sedges (Volesky et al. 2005). Needleandthread and prairie junegrass tussocks were widely distributed throughout the pastures with the exception of interdunal sites. Given these differences, it appeared that cattle were selecting diets based primarily on availability and greenness in the spring, regardless of plant growth form or distribution.

Table 2. Percentage composition of species or plant group in diets from esophageally-fistulated cows grazing upland Sandhills range during spring, 2000 and 2001. Within species or group, means with unlike letters significantly differ $(P<0.05)$.

\begin{tabular}{|c|c|c|c|c|c|c|c|c|c|}
\hline Date & Sedges & Needleandthread & Bluegrasses & $\begin{array}{c}\text { Prairie } \\
\text { junegrass }\end{array}$ & $\begin{array}{l}\text { Other cool-season } \\
\quad \text { grasses }^{1}\end{array}$ & $\begin{array}{l}\text { Prairie } \\
\text { sandreed }\end{array}$ & $\begin{array}{c}\text { Other warm-season } \\
\text { grasses }\end{array}$ & Forbs & Residual $^{2}$ \\
\hline & - & 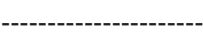 & & & --- & ------- & -2 & 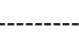 & --------- \\
\hline 10 April & $21.7 \mathrm{a}$ & 28.8 & 27.4 & $1.7 \mathrm{a}$ & $3.2 \mathrm{a}$ & $0.0 \mathrm{a}$ & $0.0 \mathrm{a}$ & 0.3 & $17.3 a$ \\
\hline 1 May & $18.8 a b$ & 29.1 & 26.8 & $5.5 b$ & $6.6 b$ & $1.1 \mathrm{~b}$ & $1.6 b$ & 1.1 & $9.8 b$ \\
\hline 22 May & $15.7 b c$ & 29.5 & 23.8 & $4.8 b$ & $5.9 b$ & $8.8 \mathrm{c}$ & $7.6 \mathrm{c}$ & 1.4 & $2.9 \mathrm{c}$ \\
\hline$\pm \mathrm{SE}$ & 1.9 & 2.3 & 2.3 & 1.0 & 0.9 & 0.9 & 0.7 & 0.7 & 1.7 \\
\hline
\end{tabular}

${ }^{1}$ Other cool-season grasses were primarily western wheatgrass and Scribner's panicum.

${ }^{2}$ Residual consisted of dead, previous year herbage. 
Table 3. Relative preference index values for plant species in diets from esophageally-fistulated cows grazing upland Sandhills range during spring, 2000 and $2001^{1}$. Within species or group, means with unlike letters significantly differ $(P<0.05)$.

\begin{tabular}{|c|c|c|c|c|c|c|c|c|c|}
\hline Date & Sedges & Needleandthread & Bluegrasses & $\begin{array}{c}\text { Prairie } \\
\text { junegrass }\end{array}$ & $\begin{array}{l}\text { Other cool-season } \\
\text { grasses }^{2}\end{array}$ & $\begin{array}{c}\text { Prairie } \\
\text { Sandreed }\end{array}$ & $\begin{array}{c}\text { Other warm-season } \\
\text { grasses }\end{array}$ & Forbs & Residual $^{3}$ \\
\hline & ---- & -------- & -------------'- & ---------- & ative preference inde & 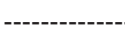 & 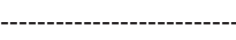 & & 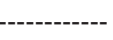 \\
\hline 10 April & $4.0 \mathrm{a}$ & $7.8 \mathrm{a}$ & 8.4 & 3.2 & 2.3 & -4 & -4 & 0.4 & $0.20 \mathrm{a}$ \\
\hline 1 May & $2.2 b$ & $4.6 \mathrm{~b}$ & 8.9 & 5.2 & 2.8 & 1.2 & 1.6 & 0.6 & $0.14 b$ \\
\hline 22 May & $1.6 b$ & $3.4 b$ & 7.2 & 5.6 & 1.5 & 1.5 & 1.1 & 0.4 & $0.06 c$ \\
\hline$\pm \mathrm{SE}$ & 0.4 & 0.6 & 1.5 & 1.7 & 0.6 & 0.5 & 0.4 & 0.4 & 0.02 \\
\hline
\end{tabular}

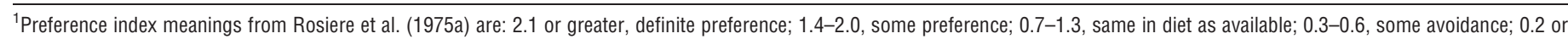
less, avoidance.

${ }^{2}$ Other cool-season grasses were primarily western wheatgrass and Scribner's panicum.

${ }^{3}$ Residual consisted of dead, previous year herbage.

${ }^{4}$ Current-year growth of prairie sandreed and other warm-season grasses was not present in pastures or diets on 10 April and not included in the analysis.

Forbs were an exception as RPI values indicated some avoidance at all sampling dates (Table 3 ). The study pastures contained several different annual and perennial forbs species that accumulated biomass comparable to some of the graminoid species. Forbs species included western ragweed (Ambrosia psilostachya DC.), western yarrow (Achillea millefolium L.), cudweed sagewort (Artemisia ludoviciana Nutt.), common sunflower (Helianthus annus L.), stiff sunflower (Helianthus rigidus [Cass.] Desf.), cutleaf ironplant (Haplopappus spinulosus [Pursh] DC.), clammy groundcherry (Physalis longifolia Nutt.), and slimflower scurpea (Psoralea tenuiflora Pursh). Most of these species, with the exception of stiff sunflower (Reece et al. 2004), are generally considered to be relatively low in palatability.

\section{Diet Quality}

Crude protein $(\mathrm{CP})$ content of diet samples were significantly less on 10 April $(10.7 \%)$ compared to 1 May and 22 May (ave. $13.9 \%, P<0.05$, Table 4$)$. Increases in nutrient value corresponded to declines in acid detergent fiber (ADF) on 10 April compared to the other dates $(P<0.05)$, whereas neutral detergent fiber (NDF) was similar across grazing dates $(P>0.05)$. During April and May, growth stages of the primary coolseason species in the study pastures mostly ranged from earlyto late-vegetative. On 22 May, however, some needleandthread plants were beginning stem elongation. An exception was sun sedge, which matures earlier than grasses and is often in anthesis in April (Hermann 1970). However, nutrient content of sedge herbage would be expected to be relatively high throughout the spring because of its high leaf:stem ratio. The lower CP content of diets on 10 April was likely because of the higher proportion of stems and residual herbage that occurred in 10 April diets compared to other dates (Fig. 1).

Lardy et al. (2004) reported similar CP and ADF content of range diets in April (10.1\% and 38\%), but NDF was higher than our reported values. They did not collect samples in May. The overall quality of diets during the April and May sampling periods was markedly higher than that reported on similar range during December and February (i.e., dormant season) when CP averaged $5.6 \%$ and ADF averaged $47.5 \%$ (Hollingsworth et al. 1995). Meadow hay, which is typically fed to spring-calving cows during April, ranges from $7 \%$ to $9 \%$ CP
(Lardy et al. 2004). Crude protein content of diets in April and May would meet requirements of a mature, spring-calving cow with average milking ability (National Research Council 1984). However, CP content on 10 April could be deficient for cows with superior milking ability.

\section{MANAGEMENT IMPLICATIONS}

Cows grazing upland Sandhills range in April and May exhibit preference for current-year growth of graminoid species and are able to select diets that can meet nutrient requirements of dry cows and lactating animals with average milking ability. However, early spring grazing as a method of extending the grazing season has limited potential, unless pastures could be stocked at low rates and/or cattle receive supplementation to meet a desired level of nutrient intake. Yield of current-year herbage on 10 April was $113 \mathrm{~kg} \cdot \mathrm{ha}^{-1}$ with tiller height averaging about $5 \mathrm{~cm}$. Potential stocking rate would be as low as 2 AUD (animal unit days) $\cdot \mathrm{ha}^{-1}$, assuming $25 \%$ utilization of the low-growing and widely-dispersed current-year herbage. Cattle stocked at higher rates would need to rely heavily on low quality residue from the previous year and/or supplementation. Current-year herbage yield on 1 May was about twice as much as 10 April, indicating a potential stocking rate of $4 \mathrm{AUD} \cdot \mathrm{ha}^{-1}$ on May 1 , which is still relatively low. By 22 May, herbage availability and potential stocking rate were

Table 4. Percentage crude protein (CP), acid detergent fiber (ADF), and neutral detergent fiber (NDF) of diets from esophageally-fistulated cows grazing upland Sandhills range during spring, 2000 and $2001^{1}$. Within quality characteristic, means with unlike letters significantly differ $(P<0.05)$.

\begin{tabular}{lccc}
\hline Date & CP & ADF & NDF \\
\hline & - & $(\%)$ & --- \\
10 Apr & $10.7 b$ & $43 a$ & 59 \\
1 May & $14.2 a$ & $38 b$ & 58 \\
22 May & $13.5 a$ & $38 b$ & 56 \\
\pm SE & 0.7 & 0.8 & 1.9 \\
\hline
\end{tabular}

${ }^{1}$ Dry matter basis. 
considerably higher than on earlier dates. In April and early May, a rapid rotation of cattle through a set of pastures with short grazing periods is a possible management strategy. If stocking rates were appropriate for current-year herbage availability, nutrient intake and livestock performance would be acceptable. Volesky et al. (2005) reported that production of warm-season grasses was not compromised at low to moderate stocking rates ( 3 to 9 AUD $\cdot \mathrm{ha}^{-1}$ ) during spring. Spring grazing also results in cool-season graminoids being consumed at a time when their nutritive value is high. Quality and palatability of most species, particularly needleandthread, declines substantially if grazing is delayed until late spring or early summer. Annually grazing pastures in spring, however, might negatively affect these species because cattle prefer current-year growth of cool-season graminoids at this time. Coyne et al. (1995) reported defoliation at an early vegetative stage reduced carbohydrate replenishment and subsequent plant production. Defoliation at the elongation stage could also negatively impact plant survival and productivity (McLean and Wilkeem 1985; Mousel et al. 2003). Periodic spring deferment might be needed to maintain a desired composition of cool-season graminoids in Sandhills plant communities.

\section{ACKNOWLEDGMENTS}

The authors would like to thank Kent Eskridge for his assistance with analytical models and procedures.

\section{LITERATURE CITED}

Adams, D. C., R. T. Clark, S. A. Coady, J. B. Lamb, and M. K. Neilson. 1994. Extended grazing systems for improving economic returns from Nebraska Sandhills cow/calf operations. Journal of Range Management 47:258-263.

Bleed, A. S., And C. A. Flowerday. 1998. An atlas of the sandhills. Lincoln, NE: University of Nebraska-Lincoln. Resource Atlas No. 5b. 265 p.

Barnes, P. W., and A. T. Harrison. 1982. Species distribution and community organization in a Nebraska Sand Hills prairie as influenced by plant/soil water relationships. Oecologia 52:192-201.

Coady, S. A., and R. T. Clakk. 1993. Ranch management practices in the Sandhills of Nebraska: managing production. Lincoln, NE: University of NebraskaLincoln, Agricultural Research Division Research Bulletin RB-318. 66 p.

CoYne, P. I., M. J. TrLICA, AND C. E. OwensBy. 1995. Carbon and nitrogen dynamics in range plants. In: D. J. Bedunah and R. E. Sosebee (ED.). Wildland plants: physiological ecology and developmental morphology. Denver, CO: Society for Range Management. p 59-167.

Ellis, J. E., J. A. Wiens, C. F. Rodell, and J. C. Anway. 1976. A conceptual model of diet selection as an ecosystem process. Journal of Theoretical Biology 60:93-108.

HarkeR, K. W., D. T. Torell, and G. M. Van Dyne. 1964. Botanical examination of forage from esophageal fistulas in cattle. Journal of Animal Science 23: 465-469.

Hermann, F. J. 1970. Manual of the carices of the Rocky Mountains and Colorado Basin. Agricultural Handbook 374. Washington, DC: US Department of Agriculture Forest Service. 397 p.

Holecheck, J. L., M. Vavra, J. Skovlin, and W. C. Krueger. 1982. Cattle diets in the Blue Mountains of Oregon, USA, I. grasslands. Journal of Range Management 35:109-112.

Hollingsworth, K. J., D. C. Adams, T. J. Klopfenstein, J. B. Lamb, and G. Villalobos. 1995. Supplement and forage effects on fecal output estimates from an intraruminal marker device. Journal of Range Management 48:137-140.
Hollingsworth-Jenkins, K. J., D. C. Adams, T. J. Klopfenstein, J. B. Lamb, and G. VILLALOBOS. 1996. Ruminally degradable protein requirement of gestating beef cows grazing Sandhills range. Journal of Animal Science 74:1343-1348.

KIRBY, D. R., And M. Parman. 1986. Botanical composition and diet quality of cattle under a short duration grazing system. Journal of Range Management 39:509-512.

Krueger, W. C. 1972. Evaluating animal forage preference. Journal of Range Management 25:471-475

Lardy, G. P., D. C. Adams, T. J. Klopfenstein, and R. T. Clark. 1999. First limiting nutrient for summer calving cows grazing autumn-winter range. Journal of Range Management 52:317-326.

Lardy, G. P., D. C. Adams, T. J. Klopfenstein, and H. H. Patterson. 2004. Building beef cow nutritional programs with the 1996 NRC beef cattle requirements model. Journal of Animal Science 82(E. Suppl.):E83-E92.

Littell, R. C., G. A. Milliken, W. W. Stroup, and R. D. Wolfinger. 1996. SAS system for mixed models. Cary, NC: SAS Institute, Inc. 633 p.

McLean, A. And S. WilkeEm. 1985. Influence of season and intensity of defoliation on bluebunch wheatgrass survival and vigor in southern British Columbia. Journal of Range Management 38:21-26.

Mousel, E. M., W. H. Schacht, and L. E. Moser. 2003. Summer grazing strategies following early-season grazing of big bluestem. Agronomy Journal 95:12401245.

National Research Council. [NRC]. 1984. Nutrient requirements of beef cattle. 6th ed. Washington, DC: National Academy Press. 90 p.

Pfister, J. A., G. B. Donart, R. D. Pieper, J. D. Wallace, and E. E. Parker. 1984. Cattle diets under continuous and four-pasture, one-herd grazing systems in southcentral New Mexico. Journal of Range Management 37:50-54.

Powell, D. J., D. C. Clanton, and J. T. Nichols. 1982. Effect of range condition on the diet and performance of steers grazing native Sandhills range in Nebraska. Journal of Range Management 35:96-99.

Reece, P. E., W. H. Schacht, and A. E. Koehler. 2004. Stiff sunflower population dynamics on summer-grazed Sandhills rangeland. Journal of Range Management 57:590-596.

Rosiere, R. E., R. F. Beck, and J. D. Wallace. 1975a. Cattle diets on semidesert grassland: botanical composition. Journal of Range Management 28:89-93.

Rosiere, R. E., J. D. Wallace, and R. F. Beck. 1975b. Cattle diets on semidesert grassland: nutritive content. Journal of Range Management 28:94-96.

Stubbendieck, J., S. L. Hatch, and C. H. Butterfield. 1997. North American range plants. 5th ed. Lincoln, NE: University of Nebraska Press. 501 p.

Stuth, J. W. 1991. Foraging behavior. In: R. K. Heitschmidt and J. W. Stuth (EDS.). Grazing management: An ecological perspective. Portland, OR: Timber Press. p 65-84.

URESK, D. W. 1986. Food habits of cattle on mixed-grass prairie on the Northern Great Plains. Prairie Naturalist 18:211-218.

Vallentine, J. F. 1990. Grazing management. San Diego, CA: Academic Press, Inc. $553 \mathrm{p}$.

Van Soest, P. J. 1963. Use of detergents in analysis of fibrous feeds. II. A rapid method for the determination of fiber and lignin. Journal of American Association of Analytical Chemists 46:829-835.

Van Soest, P. J., J. B. Robertson, and B. A. Lewis. 1991. Methods for dietary fiber, neutral detergent fiber, and non-starch polysaccharides in relation to animal nutrition. Journal of Dairy Science 74:3583-3597.

Vavra, M., and R. J. Raleigh. 1976. Coordinating beef cattle management with the range resource. Journal of Range Management 29:449-452.

VILLALOBOS, G. 1993. Integration of complementary forage with native range for efficient beef production in the Sandhills of Nebraska [dissertation]. Lincoln, NE: University of Nebraska-Lincoln. $268 \mathrm{p}$.

Volesky, J. D., W. H. Schacht, P. E. Reece, and T. J. Vaughn. 2005. Spring growth and use of cool-season graminoids in the Nebraska Sandhills. Rangeland Ecology and Management 58:385-392.

Wallace, J. D., J. C. Free, and A. H. Denham. 1972. Seasonal changes in herbage and cattle diets on sandhill grassland. Journal of Range Management 25: 100-104. 